Images in...

\title{
Rhabdomyomatous mesenchymal hamartoma of the tongue
}

\author{
M Vaidyanathan, ${ }^{1}$ C E C S Williams, ${ }^{1}$ P R Morgan² \\ 'Department of Paediatric Dentistry, Guys and St Thomas' NHS Foundation Trust, London, UK; \\ 'Department of Oral Pathology, Guys and St Thomas' NHS Foundation Trust, London, UK
}

Correspondence to M Vaidyanathan, minavaidyanathan@hotmail.co.uk

\section{DESCRIPTION}

\section{Presenting problem}

A healthy 14-month-old South American girl presented with a soft tissue swelling on the left lateral border of her tongue, which had been present at birth and had gradually increased in size. The lesion was white in colour, $1.5 \mathrm{~cm}$ in size, well circumscribed and mobile (figure 1).

\section{Clinical management}

Following consultation with the Department of Oral Surgery, surgical excision of the swelling was carried out

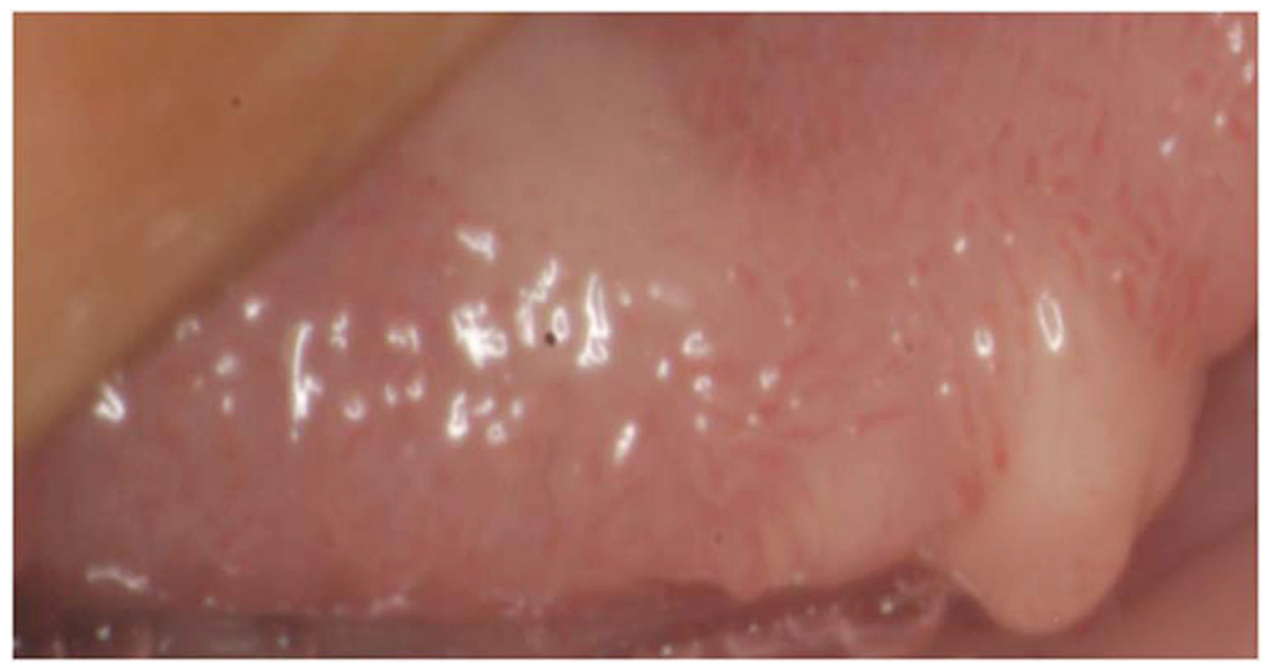

Figure 1 Clinical photo showing lesion on lateral border of the tongue.

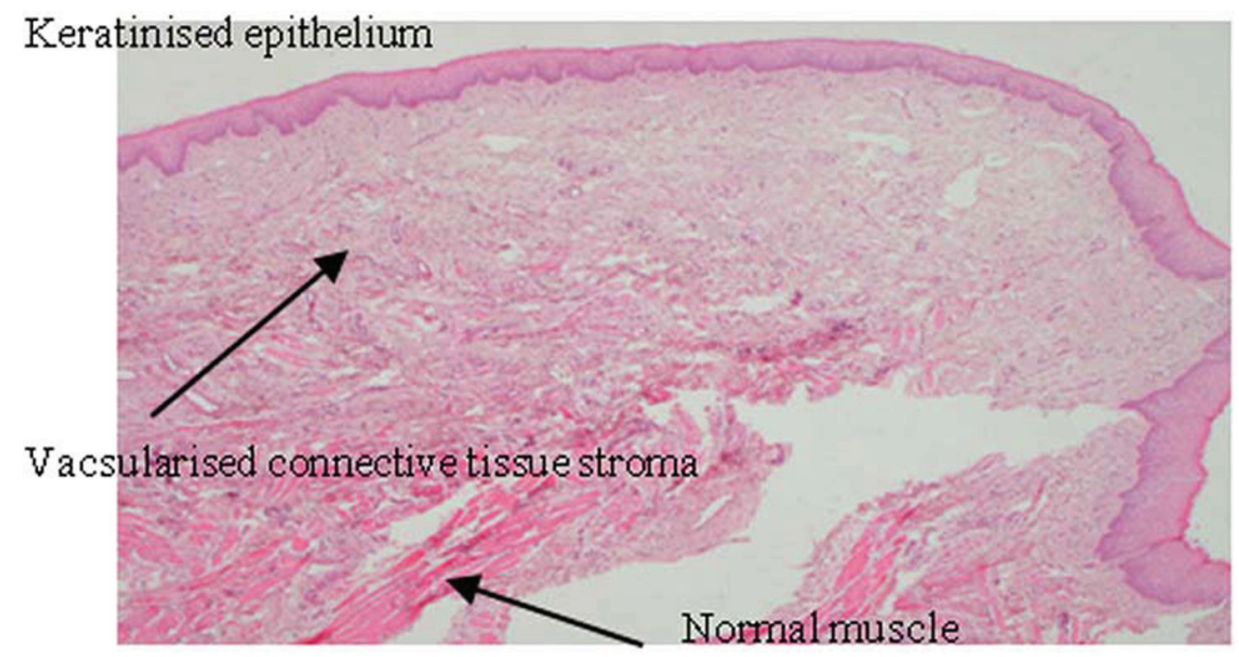

Figure 2 Histological slide of H\&E staining - low power. 


\section{BMJ Case Reports}

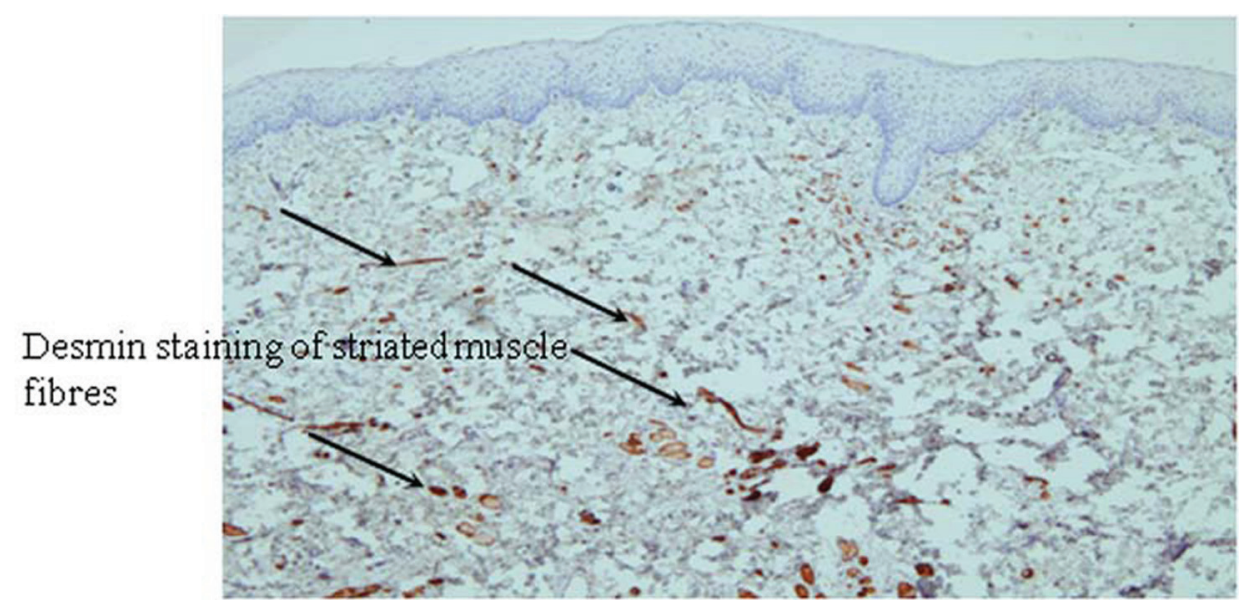

Figure 3 Desmin staining to identify striated muscle characteristically found in the connective tissue in these lesions (brown staining).

under general anaesthesia. The swelling was sent for histological examination and a diagnosis of rhabdomyomatous (mesenchymal) hamartoma of the tongue (RMH) was made (figures 2 and 3). At the most recent follow-up appointment 2 years postsurgery there has been no reoccurrence.

\section{DISCUSSION}

$\mathrm{RMH}$ is a rare congenital tumour occurring on the face and in the head and neck. Like other hamartomas they are composed of a mixture of tissues including mature adipose tissue, skeletal muscle, adnexal structures and sometimes blood vessels and nerves. The aetiology is unknown but theories proposed include migration of the mesodermally derived tissues or genetic factors. It can also be associated with congenital abnormalities such as Delleman's syndrome. RMH very rarely presents intraorally on the tongue with isolated cases reported in the literature. ${ }^{12}$ Reoccurrence of RMH in the oral cavity is very rare. This case highlights the importance of including hamartomas as a differential diagnosis for soft tissue intraoral swellings in children.

\section{Competing interests None.}

Patient consent Obtained.

\section{REFERENCES}

1. De la Sotta $\mathbf{P}$, Salamone C, Gonzalez S. Rhabdomyomatous (mesenchymal) hamartoma of the tonque: report of a case. J Oral Pathol Med 2007:36:58-9.

2. Magro G, Di Benedetto A, Sanges G, et al. Rhabdomyomatous mesenchymal hamartoma of oral cavity: an unusual location for such a rare lesion. Virchows Arch 2005; 446:346-7

This pdf has been created automatically from the final edited text and images.

Copyright 2011 BMJ Publishing Group. All rights reserved. For permission to reuse any of this content visit http://group.bmj.com/group/rights-licensing/permissions.

BMJ Case Report Fellows may re-use this article for personal use and teaching without any further permission.

Please cite this article as follows (you will need to access the article online to obtain the date of publication).

Vaidyanathan M, Williams CECS, Morgan PR. Rhabdomyomatous mesenchymal hamartoma of the tongue. BMJ Case Reports 2011; 10.1136/bcr.08.2010.3225, date of publication

Become a Fellow of BMJ Case Reports today and you can:

- Submit as many cases as you like

- Enjoy fast sympathetic peer review and rapid publication of accepted articles

- Access all the published articles

- Re-use any of the published material for personal use and teaching without further permission

For information on Institutional Fellowships contact consortiasales@bmjgroup.com

Visit casereports.bmj.com for more articles like this and to become a Fellow 